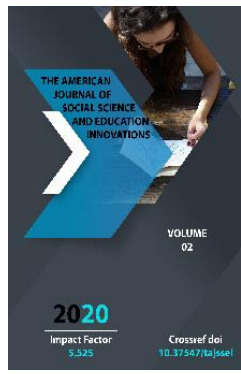

\title{
Addresses To Theotoponyms In Uzbek Toponymy
}

\author{
Sh.Turdikulov \\ Lecturer, Termez State University, Uzbekistan
}

Copyright: Original

content from this work may be used under the terms of the creative commons attributes 4.0 licence.

\section{ABSTRACT}

The collection and study of rich and varied material on the toponymy of Uzbekistan in different regions is one of the most significant areas of Uzbek linguistics. As a result of scientific research in recent years, a number of monographs have been published on the analysis of toponymy of a number of regions of Uzbekistan from a linguistic, historical and typological point of view, research has been carried out, and explanatory dictionaries of toponyms have been compiled. However, the question of the study of theotoponyms that differ linguistically and culturally among toponyms has not been resolved.

\section{KEYWORDS}

Study of toponyms, theotoponyms, theotoponyms on the example of Surkhan oasis.

\section{INTRODUCTION}

Theotoponyms do not refer to scientific objects in Uzbek toponymy. In other words, the concept of theotoponyms is an almost unknown source even in world linguistics. In most cases, theotoponyms are confused with necronyms, instead of theotoponyms there are place names derived from the names of real people, as well as toponyms composed of ethnic and significant legends. For example, there is a significant diversity between the origin of the toponym Khorezm and the etymology of the Prophet's Island, located on the banks of the Amu Darya in the Surkhandarya region. That is, both toponyms do not have a theotoponym sign. In particular, the historian S.P. Tolstov tries to prove the 
etymology of Khorezm on the basis of legends (Khor + rezm + meat + wood $=$ the husband of people who live by the river, fishing and looking for firewood) [1], similarly, in science, "The Land of the Plain" (Klippert, Lerch), "The Fertile Land" (Zachary, Geiger), "The Chorus", "The Land of Emon"(Yuti, Spiegel), "Hox + razm - prone to war, warrior" (A.Vamberi), "Hur + amin" - hur, hurshid + sun "Sun land" (Savelev, Grekov) [2]; there are also comments that "Surrounded" (N. Bogolyubov) [3]. Including S.P. Tolstoy writes that "the ancient names of countries are mostly associated with ethnic (people, tribes) names, and these names are derived from legends," which may mean Khorezm - Hvarri + land, meaning "the land of the Hvarri tribe." In addition, Khorezm has historically been interpreted as the birthplace of Zoroastrianism as Khvar (sun) + land (earth, land) = land of the sun.

\section{THE MAIN FINDINGS AND RESULTS}

In general, in Uzbek onomastics there are many references to the names of places of divine significance. For example, H. Hasanov, quoting some notes on the geography of Central Asia (especially Uzbekistan), emphasizes that the word Tianshan, which is common to the fraternal peoples of the region, in fact has a divine etymology. That is, in his view, Tianshan is a cartographic mess without a local horse. Because the locals called this mountain (mountain range - T.Sh.) Tangritog before the arrival of the Arabs. In this regard, the views of W. W. Barthold: "These mountains were considered sacred by different peoples, who believed that this mountain was the abode of divine power." However, there are reports that the Tashkent historian Muhammad Haydar Mirza (16th century) called these mountains the mountains of Mongolia.

The highest peak of Tangritog (now Pobeda Peak) is called Khantangri (Khan of sky Mountain). Over time, only part of this mountain range has survived as Tangritog, but the highest peak is still called Khantangri. In the same way, since the ancient Turkic name Tangritog began to be pronounced by the Chinese as Tyan (sky), Shan (mountain), A. Humboldt, who lived in the XIX century, introduced this name into wide scientific use.

However, the available references do not confirm a serious study of Uzbek theotoponyms. Due to the lack of scientific comments of researchers in this area, it is always important to study the theotoponyms of the region, their linguoculturological, lexicographic research. Therefore, there are such theotoponyms in the Surkhandarya oasis, the etymology of which is extremely important to determine their place in the life of the people, in the scale of values.

Surkhandarya region is bordered by Kashkadarya region in the northwest, Turkmenistan in the southwest, Tajikistan in the north and east, and Afghanistan in the south. There are 12 districts in the region (Termez, Muzrabat, Qizirik, Bandikhan, Uzun, Kumkurgan, Sherabad, Boysun, Jarqurghon, Shurchi, Denau, Sariosiyo).

Kipchaks are a major component of the ethnogenesis of the Uzbek people. The Kipchaks participated in the formation of many Turkic peoples - Kazakhs, Kyrgyz, Karakalpaks, Turkmens, Tatars, Bashkirs, Altai and some peoples of the North Caucasus - Nogay, Kumik, Karachay. The Kipchak ethnic element also included Ottoman Turks, Hungarians, and other peoples. The Kipchaks in present-day Uzbekistan gradually assimilated into the surrounding Uzbeks as a result of intermingling ethnic groups.[5]

Ancient and old Kipchak inscriptions have been preserved to this day and are being studied in depth by archaeologists, ethnographers and linguist Turkologists. Kipchak, along with Oghuz, Bulgar, and Qarluq, belongs to the western Hunnic group of Turkic languages [6]. It is located between the Qarluq and Oghuz languages and is closer to the latter [7]. 
The Kipchak dialect zone of the Uzbek language has a very large territory and consists of a group of Uzbek tribes. Kipchak dialects are available in all regions, districts of Uzbekistan and abroad. It includes the corresponding phenomena of the general Kipchak area of the Uzbek language, with the dialects forming dialect zones and dialect groups, rather than individual dialects in the regions where they are located. Kipchak dialects of the Uzbek language have been studied mainly since the second decade of the 2oth century.

Yo. Khojamberdiev, a scholar of Surkhandarya toponyms, notes that place names have at least three important meanings:

1. Place names indicate the exact location. Whenever a person travels in an airplane, train, car, or on foot, his or her movement is directed to a specific object, a specific destination, with a specific purpose. Otherwise, aimless, aimless action will be useless. The importance of this can be illustrated by a small example. The ambulance is told that the patient is in critical condition, but if the address is not clear, the ambulance will not be able to save the patient from a serious accident, no matter how fast he goes. Because the action is not focused on a specific object, address.

2. Place names provide precious information about the past history of peoples. This can be illustrated by the example of the toponym "Kirgintepa" in Sayrob village of Boysun district (also the toponymist $\mathrm{H}$. Hasanov describes the name of the Iron Gate gorge in the Boysun mountains, its origin: In the 7th century, it was written as Tamir Kapug, which in Persian-Tajik sources was called Dari-Ahanin and Darbandi Ohanin (dar - gate, iron - iron), in Arabic as Bob ul-Hadid (chapter - gate, h a d i d - iron). Now it is called Jeleznie $\mathrm{V}$ o $r$ o $t$ a in Russian. So there are four different utterances in the four languages, but the meaning is the same. (It is possible to cite the notes that this tree has the local names Buzgolakhona - "Goat Room" and "Kohlug" [4] - T.Sh.).

3. Place names also have educational value. Each place name has a reason for its name and its own history. It is a good tradition in Germany that at the beginning of a street or next to the names of other historical places, their history is briefly written on a blackboard, indicating the reason for their appropriation [9]. When information about the reasons for the names of streets, villages, mountains, cities and other places is published from time to time in the press, talks and lectures, excursions are organized, people learn about the history of their region and peoples associated with it and their love for their homeland increases. That is why it has attracted the attention of historians, ethnographers, geographers and linguists since ancient times.

\section{CONCLUSION}

In short, the toponymy of Uzbekistan is wealthy and invaluable for science. Its range of distribution is also very wide. The scientificlinguistic study of the system of toponyms of Uzbekistan is still in its infancy. Accordingly, it is advisable to start this work with the collection and verification of geographical names in the provinces. This is actually the case.

The composition of colorful place names in one of the southern regions of Uzbekistan Surkhandarya region - has not yet been fully studied. It is obvious that the beginning and successful implementation of such scientific work is undoubtedly useful for linguistics, as well as for the Uzbek people and related disciplines such as history, ethnography, geography of Uzbekistan and their specific areas. 


\section{REFERENCES}

1. Tolstov S. P. In search of ancient Khorezm culture. Tashkent: Fan, 1964, - p. 88.

2. Grekov B. // Pravda Vostoka, 1943, May 9.

3. The ancient world. Moscow: 1962. -pp. 367-370.

4. Hasanov H. From the history of Central Asian place names. Tashkent: Fan, 1965. - p. 20.

5. Shaniyazov K. Sh. To the ethnic history of the Uzbek people. Tashkent: 1974. p. 104.

6. Baskakov N.A. To the question of the classification of Turkic languages. Moscow: Izvestiya A.N. SSSR, 1952. T. $\mathrm{XI}$, issue. 2. - p.124.

7. Tenishev E.R. On the connection of vowel harmony with agglutination in Turkic languages. // Morphological typology and the problem of language classification. Moscow: 1971.

8. Shiraliev M. Kipchak elements in the Azerbaijani language // Issues of Uzbek language and literature. Tashkent: 1971. Issue 5 .

9. Nikonov V.A. The scientific significance of microtoponymy. Microtoponymy. Moscow: Moscow State University Publishing House, 1967. - p. 7.

10. Kurbanazorova, N. (2020). Linguistic Study of some Uzbek Ethnographisms Expressing Wedding Ceremonies. International Journal of Psychosocial Rehabilitation, (5), 3735-3740.

11. Kurbonazarova, N. S. (2020). The Linguocultural Aspect Of Ethnographic Units In The Linguistic System (The Example Of Wedding Ceremonies In Surkhandarya). The American Journal of Social Science and Education Innovations, 2(10), 259-263.

12. Turdikulov, S. D. (2020). Ethnolinguistic features of surkhandarya microtoponyms (on the example of theotoponyms). ISJ Theoretical \& Applied Science, 04 (84), 81-83. 